\title{
Developing local-based invertebrates e-encyclopedia to improve scientific reasoning skills
}

\author{
Maisuna Kundariati a,1, ${ }^{*}$, Fatchur Rohman ${ }^{a, 2}$ \\ a Department of Biology, Faculty of Mathematics and Science, Universitas Negeri Malang, JI Semarang 5 Malang, East Java, 65145 \\ Indonesia \\ maisunakundariati@gmail.com* ${ }^{*}{ }^{2}$ fatchur.rohman.fmipa@um.ac.id \\ * Corresponding email
}

ARTICLE INFO
Article history
Received April 26, 2020
Revised June 16, 2020
Accepted June 30, 2020
Published July 21, 2020
Keywords
21'st Century skills
e-encyclopedia
Local potency
Scientific reasoning skills

\section{ABSTRACT}

Acknowledging that it is one of the important of 21 st Century skills, scientific reasoning skills have been developed in various ways. However, the development based on local potential has not been optimally explored yet. The aim of this research was to produce e-encyclopedia of invertebrates based on local potency to improve students' scientific reasoning skills. This research and development was done, based on Lee and Owen development model, between July and December 2019. This research involved 29 students of Biology Department, Universitas Negeri Malang who have passed their third semester. The validity of e-encyclopedia was determined by conducting expert appraisal consisted of the instructional and technical review. The assessments towards e-encyclopedia was done to decide its validity, practicality, and effectiveness. Furthermore, the students' scientific reasoning skills were measured using pretest and posttest. The validity data obtained were analyzed descriptively using percentage, while students' scientific reasoning skills were analyzed using gain scores. The results showed that the percentage values were 84.72 for content validity (valid), 98.10 for media (very valid), 87.41 for technical (very valid), and 84.47 for practicality (valid). In addition, the students' scientific reasoning skills were classified as effective based on the gain scores achieved in each indicator i.e. 0.44 (argumentation), 0.43 (existing knowledge), 0.38 (methodology), 0.40 (analysis), and 0.42 (drawing conclusions). Thus, the e-encyclopedia developed is effective to improve students' scientific reasoning skills.

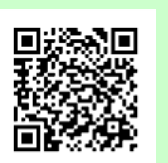

Copyright $\odot$ 2020, Kundariati \& Rohman This is an open access article under the CC-BY-SA license

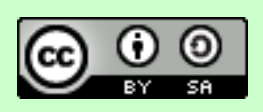

How to cite: Kundariati, M \& Rohman, F. (2020). Developing local-based invertebrates e-encyclopedia to improve scientific reasoning skills. JPBI (Jurnal Pendidikan Biologi Indonesia), 6(2), 189-198. doi: https://doi.org/10.22219/jpbi.v6i2. 11953

\section{INTRODUCTION}

Exploration of the southern coast in the Malang Regency is increasing in line with the development of tourism. Various potential local resources that stretch along the coastline attract the attention of many researchers. Research related to regional characteristics (Semedi et al., 2019), ecotourism development (Harahab \& Setiawan, 2017; Riniwati et al., 2017), disaster mitigation (Nugroho \& Sucipto, 2020), localwisdom (Rahmaniar et al., 2019), and biodiversity (Purnomo, 2020; Sari et al., 2015) has opened up the 
potential of coastal areas in South Malang. However, those research's development as a learning resource has not been optimally carried out into a paradox. Kondang Merak Beach, one of the areas on the South Coast, has quite a high diversity of invertebrates.

The beach characteristic is quite calm and surrounded by peaks and coral rocks to protect the coastal ecosystem (Nugraha et al., 2016). These characteristics are very distinctive because most beaches in the southern region are steep, rocky, and have cliffs. This uniqueness makes the coral reef population at Kondang Merak Beach avoid the swift waves and currents from the open waters (Nugraha et al., 2016). Various groups of Coelenterates and Mollusca are reported to have been found along the southern coastline (Luthfi et al., 2017; Luthfi et al., 2018). The high level of biodiversity is an essential asset in conserving natural resources, one of which is through the development of learning resources based on local potential (Kundariati et al., 2020; Kurniawati et al., 2017; NEA, 2010).

The utilization of resources as local potential is a strategic step that provides many benefits. (Ardan, 2016; Parmin et al., 2015) reported that the utilization of local potential as a learning resource had a significant impact on students' knowledge. Moreover, it is easier for teachers to link learning skills or competencies with the student learning environment (Donnelly et al., 2017; Hussin, 2018). The utilization of local potential can also be directed as an effort to support 21st Century learning (Binkley et al., 2012; Hussin, 2018; Jumriani \& Prasetyo, 2017). Some researchers state that the integration of local potential as a learning resource can facilitate students in scientific reasoning (Glaze, 2018; Kambeyo, 2017; Ogunkola, 2013). These efforts help students build cognitive understanding in a more profound way (Daryanti et al., 2015).

However, Erlina et al (2018) show that students' scientific reasoning skills are still low. Even though scientific reasoning skills are one of the skills that students must have, referring to the profile of $21^{\text {st }}$ Century students (Kambeyo, 2017; Khoirina et al., 2018; Kuhn, 2010). Scientific reasoning skills in question refer to students' ability to analyze, express opinions, and draw conclusions based on their understanding (Rhodes, 2010). Furthermore, these three components will lead to making the right decisions based on relevant evidence (Abosalem, 2016; Freidenreich et al., 2011; McNeill et al., 2012).

This research aims to develop an e-Encyclopedia of invertebrates as a learning resource based on the local potential of Kondang Merak Beach. The e-Encyclopedia draft that has been developed is then tested to measure the students' ease and usefulness. The effectiveness test is used to determine whether the product developed supports learning in improving students' scientific reasoning. The results of this study are expected to contribute to the development of instructional media that improve thinking skills based on local potential.

\section{METHOD}

This research consists of exploratory research and media development while it was conducted from July to December 2019. The exploratory research was conducted at Kondang Merak Beach, Malang Regency. Sampling was carried out using free-roaming techniques to ensure that no specimen was left behind. Product development refers to Lee and Owens (2004) model, which is correctly used to develop multimedia-based products. The stages of development carried out consist of: assessment/analysis; design; development; implementation; and evaluation.

The subjects in this study were lecturers and students of Biology Education Department the year 2018 State University of Malang. The types of data contained in this study consists of qualitative and quantitative data. The qualitative data were obtained from experts and practitioners, while the quantitative data were obtained from assessments by validators and students as users. The assessment is carried out using a rating scale and students' scientific reasoning scores. The data collection instruments consisted of instruments of validity, practicality, and effectiveness. The results of the product evaluation questionnaire were analyzed using descriptive analysis in the form of a percentage. The criteria for product validity and practicality (Table 1) refer to Gay et al (2012).

Table 1. Product validity assessment qualification criteria

\begin{tabular}{lcl}
\hline \multicolumn{1}{c}{ Practicality } & Percentage (\%) & \multicolumn{1}{c}{ Validity } \\
\hline $\begin{array}{l}\text { Very practical or can be used } \\
\begin{array}{l}\text { Pretty practical or can be used but needs a little } \\
\text { revision }\end{array}\end{array}$ & $\begin{array}{l}85.01-100 \\
\text { Less practical, it is recommended not to use it }\end{array}$ & $\begin{array}{l}\text { Very valid or can be used } \\
\text { Quite valid or can be used but needs a little revision }\end{array}$ \\
$\begin{array}{l}\text { because it needs a lot of revisions } \\
\text { Impractical or may not be used }\end{array}$ & $50.01-70.00$ & $\begin{array}{l}\text { Invalid, it is recommended not to use it because it } \\
\text { needs a lot of revisions }\end{array}$ \\
\hline
\end{tabular}


The effectiveness of the e-encyclopedia in improving students' scientific reasoning was measured using the gain score formula. The effectiveness criteria used refer to Erlina et al (2018), are the products presented in Table 2.

Table 2. Product effectiveness criteria

\begin{tabular}{cc}
\hline Level of achievement in value & Level of effectiveness \\
\hline $\mathrm{n}$-gain $\geq 0.7$ & Very effective \\
$0.3<\mathrm{n}$-gain $<0.7$ & Effective \\
$\mathrm{n}$-gain $\leq 0.3$ & Not effective \\
\hline
\end{tabular}

\section{RESULTS AND DISCUSSION}

The local potential has the unique characteristics of each region (Parmin et al., 2015). Malang Regency has the potential for biodiversity that can be optimized as a learning resource (Kundariati et al., 2020). Local potential-based learning can provide a more valuable experience for students because it is closer to everyday life and the environment. In line with research conducted by Hernawati et al (2018); Koban et al (2020); and Kurniawati et al (2017) concluded that learning assisted by learning sources with local potential could improve students' academic abilities. Local potential-based teaching materials also help students classify activities and improve attitudes in preserving sustainability (Lestari et al., 2018).

The exploration results showed that eight species of Coelenterates were found at Kondang Merak Beach (Table 3). Five of them are of the genus Montipora (three species) and Pocillopora (two species). Meanwhile, there are 17 species of Mollusca consisting of 15 genera. More specifically, Conus and Engina are two species each.

Table 3. The results of exploratory research on the Kondang Merak Beach

\begin{tabular}{ll}
\hline Phylum & \multicolumn{1}{c}{ Species } \\
\hline Coelenterates & 1. Pocillopora damicornis (Linnaeus, 1758) \\
2. Pocillopora verrucosa (Ellis \& Solander, 1786) \\
3. Montipora digitata (Dana, 1846) \\
4. Montipora carinata (Nemenzo, 1967) \\
5. Montipora capricornis (Veron, 1985) \\
6. Galaxea fascicularis (Linnaeus, 1767) \\
7. Hynophora exesa (Pallas, 1766) \\
8. Porites lutea (Milne Edwards \& Haime, 1851) \\
\hline 1. Conus planorbis (Born, 1778) \\
2. Conus achanitus (Gmelin, 1791) \\
3. Engina mendicaria (Linnaeus, 1758) \\
4. Engina bidentata (Menke, 1843) \\
5. Atria pectinata (Linnaeus, 1767) \\
6. Geloina expansa (Mousson, 1849) \\
7. Monetaria annulus (Linnaeus, 1758) \\
8. Naria erosa (Linnaeus, 1758) \\
9. Turbo bruneus (Roding, 1798) \\
10. Euplica varians (G.B. Soweby, 1832) \\
11. Eunaticina papilla (Gmelin, 1791) \\
12. Tonna canaliculata (Linnaeus, 1758) \\
13. Tanea undulata (Roding, 1798) \\
14. Rochia nilotica (Linnaeus, 1767) \\
15. Conomurex lahuanus (Linnaeus, 1758) \\
16. Pictocolumbella ocellata (Link, 1807) \\
17. Onchidoris billamelata (Linnaeus, 1767)
\end{tabular}

The Coelenterates and Mollusca species found were used as learning resources in the development of the e-encyclopedia. The results of the validation of material experts and practitioners show that product feasibility and readability are classified as very valid, respectively $84.72 \%$ and $87.41 \%$, as described in Table 4 . The validation of media and technical experts showed similar results. An assessment of four media validity aspects shows that the e-encyclopedia is very valid $(98.10 \%)$. More specifically, the linguistic and graphic aspect is very valid, with a percentage of $100 \%$ (Table 5). 
Table 4. Validation test results by material experts and practitioners

\begin{tabular}{clcccccc}
\hline \multirow{2}{*}{ Expert } & \multicolumn{1}{c}{ Aspect } & $\begin{array}{c}\text { Number of } \\
\text { aspect }\end{array}$ & $\begin{array}{c}\text { Maximum } \\
\text { score }\end{array}$ & $\begin{array}{c}\text { Acquisition } \\
\text { score }\end{array}$ & $\begin{array}{c}\text { Validity } \\
(\%)\end{array}$ & $\begin{array}{c}\text { Average } \\
(\%)\end{array}$ & Category \\
\hline \multirow{2}{*}{ Material } & Content eligibility & 16 & 80 & 71 & 88.75 & 84.72 & Quite valid \\
& Legibility & 11 & 55 & 48 & 87.27 & & \multirow{2}{*}{ Very valid } \\
\hline \multirow{2}{*}{ Practitioners } & Content eligibility & 16 & 80 & 69 & 86.25 & 87.41 & 89.09 \\
\end{tabular}

Table 5. Validation test results by media experts

\begin{tabular}{|c|c|c|c|c|c|c|}
\hline No & Aspect & $\begin{array}{c}\text { Number of } \\
\text { aspect }\end{array}$ & $\begin{array}{l}\text { Maximum } \\
\text { score }\end{array}$ & $\begin{array}{l}\text { Acquisition } \\
\text { score }\end{array}$ & $\begin{array}{c}\text { Validity } \\
(\%)\end{array}$ & Category \\
\hline 1 & Format & 5 & 25 & 24 & 96.00 & Very valid \\
\hline 2 & $\begin{array}{l}\text { Language and } \\
\text { readability }\end{array}$ & 6 & 35 & 35 & 100.00 & Very valid \\
\hline 3 & Presentation & 3 & 25 & 24 & 93.33 & Very valid \\
\hline 4 & Graphic & 3 & 30 & 30 & 100.00 & Very Valid \\
\hline \multicolumn{5}{|c|}{ Average score } & 98.10 & Very valid \\
\hline
\end{tabular}

In line with the expert's validation results, the product practicality test showed that the e-encyclopedia was feasible to be used as a learning media. Aspects of legibility, and benefits are classified as very practical with the percentages, respectively 87.65 and 85.66 (Table 6).

Table 6. Practical test results

\begin{tabular}{clccccc}
\hline No & Aspect & Number of aspect & Maximum score & Acquisition score & Validity (\%) & Category \\
\hline 1 & Language & 5 & 575 & 484 & 84.17 & Pretty practical \\
2 & Legibility & 5 & 575 & 504 & 87.65 & Very practical \\
3 & Presentation & 8 & 920 & 749 & 81.41 & Pretty practical \\
4 & Display & 6 & 690 & 556 & 83.48 & Pretty practical \\
5 & Benefits & 6 & 690 & 591 & 85.66 & Very practical \\
\hline
\end{tabular}

Data on scientific reasoning skills are obtained through pretest and posttest, which are integrated with scientific reasoning indicators. The measurement of the effectiveness of the product developed is to measure the increase in students' scientific reasoning skills using an $\mathrm{N}$-gain formula. The results of improvement in each indicator of scientific reasoning skills are presented in Figure 1.

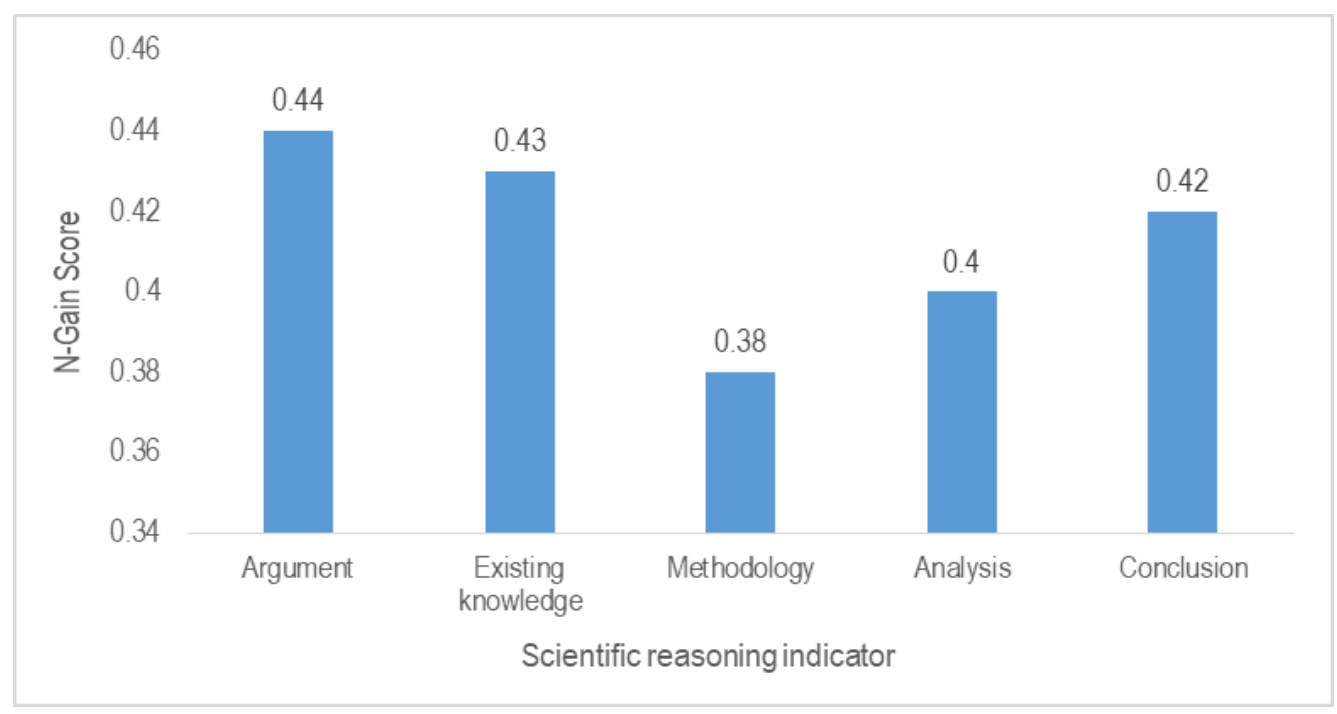

Figure 1. The N-gain score for scientific reasoning indicator

The integration of scientific reasoning skills in the development of the e-encyclopedia aims to streamline the measurement of students' thinking skills (Kambeyo, 2017). The integration of thinking skills is indicated to train students to develop their logical abilities. This prediction can be seen in the achievement of the students' $\mathrm{N}$-gain scores after using the e-encyclopedia. Learning activities designed to guide the optimization of the concept of a scientific phenomenon that is owned, in this case, related to Coelenterates and Molluscs, 
facilitate students in developing scientific thinking skills. This association is a very fundamental step to provide a more in-depth learning and thinking experience (Larsson, 2017; Tal \& Tsaushu, 2017). Many researchers said that the scientific approach requires coherence between observing skills, asking, gathering information, analyzing information, associating, and communicating again (Glaze, 2018; Nurafifah et al., 2017; Salter \& Atkins, 2014; Vieira et al., 2017).

Figure 1 shows that the e-encyclopedia effectively increases students' scientific reasoning-the students' ability to convey arguments increases through learning using the e-encyclopedia. The developing product facilitates students in identifying fundamental topics that have not been explored previously (Rhodes, 2010). Material characteristics related to diversity and classification principles encourage students to think logically. One of the students' arguments was morphological and anatomical features of animals belonging to Coelenterates and Mollusca. Students from observations obtained morphological and anatomical characteristics during the learning process. Observing in a scientific approach is an activity of sensing using various media such as images, videos, and wet and dry specimens (Retno \& Yuhanna, 2016; Sukarno et al., 2013).

Increasing students' ability to argue is supported by the knowledge they have (Baker et al., 2010; Cullen et al., 2018; Darling-Hammond et al., 2020; Noviyanti et al., 2019). Knowledge is one of the critical elements in synthesizing information in depth (Darowski et al., 2016; Kastner et al., 2012; Killi \& Leu, 2019; Lundstrom et al., 2015; Palmatier et al., 2018), supported by various relevant and credible sources (Rhodes, 2010). Thus, students can see a phenomenon more comprehensively (Ennis, 2011; Goldman et al., 2014). It has an impact on the ability to do analysis and draw conclusions. However, the study results shows that the improvement in analysis indicators is lower than the ability to argue, know, and draw conclusions. Information synthesis skills are essential in revealing patterns, differences, or similarities in the concepts studied, in this case, Coelenterates and Mollusca. An improved analysis is lower because it requires deep understanding and thought related to investigations, practicum, and theory. Animal classification material requires students to find or criticize the basic concepts of grouping animals. The basis for classifying each phylum or class is unique, so students need to analyze it through hands-on activity activities (Cinici, 2013; Kuhn, 2011). Most of them mention morphological or anatomical features that are not related to these animals' primary classification.

Furthermore, methodologies are an indicator with an N-Gain score that best develops the theoretical framework skillfully (Leow \& Neo, 2014; Yusof et al., 2012). This step needs to be formulated by students in describing and classifying animals. In this case, the description and grouping of animals are based on similarities or differences in animals' morphological and anatomical features.

The Coelenterates and Mollusca e-encyclopedia design consists of: a) scientific names, b) morphological descriptions, c) distribution, and d) conservation status accompanied by either original pictures or photos. It aims to help students obtain information as material for analysis in learning activities. In line with the statement of Hernawati et al (2018) that encyclopedia can provide visualizations to represent explanations. Apart from that, the e-encyclopedia also features synthesis and analysis. In other words, the description of species in the e-encyclopedia supports analyzing activities through student worksheets. According to Cinici (2013) analysis activities carried out by students are related to animal classification, where morphological characteristics can be used as the basis for animal classification.

As a mobile learning media, the e-encyclopedia has the advantage that it can be used flexibly by merely opening a smartphone. Mobile-based learning has been used for about 20 years in several countries (Akopian et al., 2013; Alhassan, 2016; Klimova, 2019; Sung et al., 2016; West, 2015) and provides benefits because of that flexibility (Behera, 2013; Cheung, 2015; Klimova, 2019; Miangah \& Nezarat, 2012; Mileva, 2011). Currently, the use of smartphones has become commonplace, including their use in the learning process (Akopian et al., 2013; Klimova, 2019).

Smartphone applications are useful for improving higher education learning performance by implementing mobile learning-based learning (Demir \& Akpınar, 2018; Elkhateeb et al., 2019; García-Martínez et al., 2019; Klimova, 2019; Ocran et al., 2020; Romero-Rodríguez et al., 2020; Sukardia et al., 2020; Sung et al., 2016). Learning using mobile learning can provide students with experiences and how they use mobile learning as a learning medium. It is in line with Cheung (2015) statement, which states that mobile learning can provide learning experiences and attract more students. Students who use applications on smartphones are also stimulated in formal and informal learning situations (Miangah \& Nezarat, 2012; Teodorescu, 2015). In other words, students will be able to learn inside and outside the classroom. Student activities outside the classroom can be a means of contextual learning for students. 


\section{CONCLUSION}

The development of the E-encyclopedia Coelenterates and Mollusca results from exploratory research at Kondang Merak Beach, is valid, practical, and effective to improve students' scientific reasoning skills. The results of the $\mathrm{N}$-gain calculation show that all indicators of scientific reasoning skills are classified as effective. Further development can be done by integrating a more comprehensive thinking skills assessment.

\section{ACKNOWLEDGMENT}

Gratitude and appreciation to LP2M State University of Malang for providing funding through the 2019 PNPB research fund with Number 20: 3.66/UN32.14.1/LT/2019 and also Dr. Hj. Sri Endah Indriwati, M.Pd. as the leader of this research team.

\section{REFERENCES}

Abosalem, Y. (2016). Assessment techniques and students' higher-order thinking skills. International Journal of Secondary Education, 4(1), 1-11. doi: https://doi.org/10.11648/j.ijsedu.20160401.11

Akopian, D., Melkonyan, A., Golgani, S. C., Yuen, T. T., \& Saygin, C. (2013). A template-based short course concept on android application development. Journal of Information Technology Education: Innovations in Practice, 12, 13-28. Retrieved from https://nsf.gov/awardsearch/showAward?AWD_ID=0942852

Alhassan, R. (2016). Mobile learning as a method of ubiquitous learning: students' attitudes, readiness, and possible barriers to implementation in higher education. Journal of Education and Learning, 5(1), 176. doi: https://doi.org/10.5539/jel.v5n1p176

Ardan, A. S. (2016). The development of biology teaching material based on the local wisdom of Timorese to improve students knowledge and attitude of environment in caring the preservation of environment. International Journal of Higher Education, 5(3), 190-200. doi: https://doi.org/10.5430/ijhe.v5n3p190

Baker, E. L., Barton, P. E., Darling-Hammond, L., Haertel, E., Ladd, H. F., Linn, R. L., ... Shepard, L. A. (2010). Problems with the use of student test scores to evaluate teachers. In EPI Briefing Paper (Vol. 278). Retrieved from https://files.epi.org/page/-/pdf/bp278.pdf

Behera, S. K. (2013). e- and m-learning: A comparative study. International Journal on New Trends in Education and Their Implications, 4(5), 65-78. http://ijonte.org/FileUpload/ks63207/File/08.behera.pdf

Binkley, M., Erstad, O., Herman, J., Raizen, S., Ripley, M., Miller-Ricci, M., \& Rumble, M. (2012). Defining twenty-first century skills. In P. Griffin, B. McGaw, \& E. Care (Eds.), Assessment and teaching of 21st Century skills (pp. 17-66). Springer. doi: https://doi.org/10.1007/978-94-007-2324-5

Cheung, S. K. S. (2015). A case study on the students' attitude and acceptance of mobile learning. Communications in Computer and Information Science, 494, 45-54. doi: https://doi.org/10.1007/978-3662-46158-7_5

Cinici, A. (2013). Turkish high school students' ideas about invertebrates: General characteristics and classification. International Journal of Environmental and Science Education, 8(4), 645-661. doi: https://doi. org/10.21831/jpms.v6i2.10948

Cullen, S., Fan, J., van der Brugge, E., \& Elga, A. (2018). Improving analytical reasoning and argument understanding: a quasi-experimental field study of argument visualization. Npj Science of Learning, 3(1), 1-6. doi: https://doi.org/10.1038/s41539-018-0038-5

Darling-Hammond, L., Flook, L., Cook-Harvey, C., Barron, B., \& Osher, D. (2020). Implications for educational practice of the science of learning and development. Applied Developmental Science, 24(2), 97-140. doi: https://doi.org/10.1080/10888691.2018.1537791

Darowski, E. S., Patson, N. D., \& Helder, E. (2016). Implementing a synthesis tutorial to improve student literature reviews. Behavioral and Social Sciences Librarian, 35(3), 94-108. doi: https://doi.org/10.1080/ 01639269.2016 .1243437

Daryanti, E. P., Rinanto, Y., \& Dwiastuti, S. (2015). Peningkatan kemampuan penalaran ilmiah melalui model pembelajaran inkuiri terbimbing pada materi sistem pernapasan manusia. Jurnal Pendidikan Matematika dan Sains, 3(2), 163-168. doi: https://doi.org/10.21831/jpms.v6i2.10948

Demir, K., \& Akpınar, E. (2018). The effect of mobile learning applications on students' academic achievement and attitudes toward mobile learning. Malaysian Online Journal of Educational Technology, 6(2), 48-59. 
doi: https://doi.org/10.17220/mojet.2018.02.004

Donnelly, F. C., Mueller, S. S., Gallahue, D. L., \& Gallahue, D. L. (2017). Developmental physical education for all children: Theory into practice. Human Kinetics. Retrieved from https://books.google.co.id/books? id=YPR6DwAAQBAJ

Elkhateeb, M., Shehab, A., \& El-Bakry, H. (2019). Mobile learning system for egyptian higher education using agile-based approach. Education Research International, 2019, 7531980. doi: https://doi.org/10.1155/ 2019/7531980

Ennis, R. H. (2011). The nature of critical thinking: An outline of critical thinking dispositions. Sixth International Conference on Thinking at MIT, 1-8. Retrieved from https://education.illinois.edu/docs/ default-source/faculty-documents/robert-ennis/thenatureofcriticalthinking_51711_000.pdf.

Erlina, N., Susantini, E., Wasis, W., Wicaksono, I., \& Pandiangan, P. (2018). The effectiveness of evidencebased reasoning in inquiry-based physics teaching to increase students' scientific reasoning. Journal of Baltic Science Education, 17(6), 972-985. doi: https://doi.org/10.33225/jbse/20.19.523

Freidenreich, H. B., Duncan, R. G., \& Shea, N. (2011). Exploring middle school students' understanding of three conceptual models in Genetics. International Journal of Science Education, 33(17), 2323-2349. doi: https://doi.org/10.1080/09500693.2010.536997

García-Martínez, I., Fernández-Batanero, J. M., Sanchiz, D. C., \& de la Rosa, A. L. (2019). Using mobile devices for improving learning outcomes and teachers' professionalization. Sustainability (Switzerland), 11(24), 1-12. doi: https://doi.org/10.3390/su11246917

Gay, L. R., Mills, G. L., \& Airasian, P. (2012). Educational research: Competencies for analysis and application. Pearson. Retrieved from http://englishlangkan.com/produk/E Book Educational Research L R Gay Pearson 2012.pdf

Glaze, A. (2018). Teaching and learning science in the 21st century: Challenging critical assumptions in postsecondary science. Education Sciences, 8(1), 12. doi: https://doi.org/10.3390/educsci8010012

Goldman, D., Yavetz, B., \& Pe'er, S. (2014). Student teachers' attainment of environmental literacy in relation to their disciplinary major during undergraduate studies. International Journal of Environmental and Science Education, 9(4), 369-383. doi: https://doi.org/10.12973/ijese.2014.222a

Harahab, N., \& Setiawan, S. (2017). Suitability index of mangrove ecotourism in Malang Regency. Journal of Economic and Social of Fisheries and Marine, 4(02), 153-165. doi: https://doi.org/10.21776/ub. ecsofim. 2017.004.02.05

Hernawati, D., Amin, M., Irawati, M. H., Indriwati, S. E., \& Omar, N. (2018). The effectiveness of scientific approach using encyclopedia as learning materials in improving students' science process skills in science. Jurnal Pendidikan IPA Indonesia, 7(3), 266-272. doi: https://doi.org/10.15294/jpii.v7i3.14459

Hussin, A. A. (2018). Education 4.0 made simple: Ideas for teaching. International Journal of Education and Literacy Studies, 6(3), 92-98. doi: https://doi.org/10.7575/aiac.ijels.v.6n.3p.92

Jumriani, J., \& Prasetyo, Z. . (2017). Important roles of local potency based science learning to support the 21 st Century learning. European Journal of Engineering and Formal Sciences, 1(1), 6. doi: https://doi. org/10.26417/ejef.v1i1.p6-16

Kastner, M., Tricco, A. C., Soobiah, C., Lillie, E., Perrier, L., Horsley, T., ... Straus, S. E. (2012). What is the most appropriate knowledge synthesis method to conduct a review? Protocol for a scoping review. BMC Medical Research Methodology, 12(1), 144. doi: https://doi.org/10.1186/1471-2288-12-114

Kambeyo, L. (2017). Scientific reasoning skills: A theoretical background on science education. NERA Journal, 14, 40-64. retrieved from https://www.researchgate.net/publication/329196813_scientific_ reasoning_skills_a_theoretical_background_on_science_education

Khoirina, M., Cari, C., \& Sukarmin, S. (2018). Identify students' scientific reasoning ability at senior high school. Journal of Physics: Conference Series, 1097(1), 012024. doi: https://doi.org/10.1088/1742-65 96/1097/1/012024

Kiili, C., \& Leu, D. J. (2019). Exploring the collaborative synthesis of information during online reading. Computers in Human Behavior, 95, 146-157. doi: https://doi.org/10.1016/j.chb.2019.01.033

Klimova, B. (2019). Impact of mobile learning on students achievements results. Education Sciences, 9(2), 90. doi: https://doi.org/10.3390/educsci9020090

Koban, G. H. S., Linuwih, S., \& Purwanti, E. (2020). The implementation of project-based learning model based on local food potency in developing entrepreneurship attitude of primary school students. Journal of Primary Education, 9(1), 32-41. Retrieved from https://journal.unnes.ac.id/sju/index.php/jpe/article/ view/28239 
Kuhn, D. (2010). What is scientific thinking and how does it develop? In The Wiley-Blackwell Handbook of Childhood Cognitive Development, Second edition (Issue July 2010). Teachers College Columbia University. doi: https://doi.org/10.1002/9781444325485.ch19

Kuhn, D. (2011). What is scientific thinking and how does it develop? In The Wiley-Blackwell handbook of childhood cognitive development, 2nd ed. (pp. 497-523). Wiley-Blackwell. doi: https://doi.org/10.1002/ 9781444325485.ch19

Kundariati, M., Maghfiroh, L., Indriwati, S. E., Rohman, F., Priyambodo, B., Setyawan, D., \& Azean, N. (2020). Analysis of invertebrate and vertebrate animals in Malang Regency as an animal diversity learning resource for biology student at the Universitas Negeri Malang. AIP Conference Proceedings, 2215. doi: https://doi.org/10.1063/5.0003781

Kurniawati, A. P., Prasetyo, Z. K., Wilujeng, I., \& Suryadarma, I. G. P. (2017). The effectivenes of science domain-based science learning integrated with local potency. AIP Conference Proceedings, 1868. doi: https://doi.org/10.1063/1.4995185

Larsson, K. (2017). Understanding and teaching critical thinking-A new approach. International Journal of Educational Research, 84(December 2016), 32-42. doi: https://doi.org/10.1016/j.ijer.2017.05.004

Lee, W. W., \& Owens, D. L. (2004). Multimedia-based instructional design. Pfeiffer. Retrieved from https://books.google.co.id/ books/about/Multimedia_based_Instructional_Design.html?id=QX|4ZtUug6Y C\&redir_esc=y

Leow, F. T., \& Neo, M. (2014). Interactive multimedia learning: innovating classroom education in a Malaysian University. TOJET: The Turkish Online Journal of Educational Technology, 13(2), 99-110. Retrieved from http://www. tojet.net/articles/v13i2/13211.pdf

Lestari, S., Sriyati, S., \& Amprasto, A. (2018). The utilization of bio-booklet of plants diversities based on local potency to enhance student's conservation attitudes and skills for classification. International Conference on Mathematics and Science Education, 3. Retrieved from http://science.conference.upi. edu/proceeding/index.php/ICMScE/article/view/92/84

Lundstrom, K., Diekema, A. R., Leary, H., Haderlie, S., \& Holliday, W. (2015). Teaching and learning information synthesis: An intervention and rubric based assessment. Communications in Information Literacy, 9(1), 60-82. doi: https://doi.org/10.15760/comminfolit.2015.9.1.176

Luthfi, O. M., Saputra, A. P., Mutiara, R., Arisyaputra, A. R., Sinaga, J. K., Bisel, R. M., Ika, S. N., Ria, A. M., Murti, M. . H., Girindra, L. A., Rizal, S. S., Bagus, N. M., Naufal, A., \& Raditya, N. M. (2017). Pemantaun kondisi invertebrata menggunakan metode reef check, di Perairan Selat Sempu, Kabupaten Malang. Jurnal Kelautan: Indonesian Journal of Marine Science and Technology, 10(2), 129. doi: https://doi.org/ $10.21107 / j k . v 10 i 2.2711$

Luthfi, O. M., Dewi, C. S. U., Sasmitha, R. D., Alim, D. S., Putranto, D. B. D., \& Yulianto, F. (2018). Kelimpahan invertebrata di Pulau Sempu sebagai indeks bioindikator, ekonomis penting konsumsi, dan komoditas koleksi akuarium. JFMR-Journal of Fisheries and Marine Research, 2(3), 137-148. doi: https://doi.org/10.21776/ub.jfmr.2018.002.03.1

McNeill, M., Gosper, M., \& Xu, J. (2012). Assessment choices to target higher order learning outcomes: The power of academic empowerment. Research in Learning Technology, 20(3), 283-296. doi: https:/l doi.org/10.3402/rlt.v20i0.17595

Miangah, T. M., \& Nezarat, A. (2012). Mobile-assisted language learning. International Journal of Distributed and Parallel Systems, 3(1), 309-319. doi: https://doi.org/10.5121/ijdps.2012.3126

Mileva, N. (2011). The effectiveness of mobile learning in the form of performance support system in higher education. International Journal of Interactive Mobile Technologies (IJIM), 5(4), 17-21. doi: https://doi. org/10.3991/ijim.v5i4.1692

NEA, N. (2010). Preparing 21st century students for a global society. Retrieved from http://www.nea.org/ assets/docs/A-Guide-to-Four-Cs.pdf

Noviyanti, N. I., Mukti, W. R., Yuliskurniawati, I. D., Mahanal, S., \& Zubaidah, S. (2019). Students' scientific argumentation skills based on differences in academic ability. Journal of Physics: Conference Series, 1241(1), 012034. doi: https://doi.org/10.1088/1742-6596/1241/1/012034

Nugraha, D. A., Sartimbul, A., \& Luthfi, O. M. (2016). Analisis sebaran karang di Perairan Kondang Merak, Malang Selatan. Seminar Nasional Perikanan dan Kelautan VI, May. Retrieved from https:/l www.researchgate.net /publication/309231573_analisis_sebaran_karang_di_perairan_kondang_merak malang_selatan

Nugroho, K. D., \& Sucipto, U. (2020). Pengenalan potensi dan mitigasi bencana bagi kader di Kawasan 
Wisata Pantai Selatan Malang. Jurnal Pengabdian Masyarakat Kasih STIKES Dirgahayu Samarinda, 1(2), 28-32. Retrieved from http://jkd.stikesdirgahayusamarinda.ac.id/index.php/jpmk/article/view/127

Nurafifah, A., Budi, A. S., \& Siahaan, B. Z. (2017). Developing wave encyclopedia based on scientific approach. Journal of Physics: Conference Series, 895(1), 012018. doi: https://doi.org/10.1088/1742$6596 / 895 / 1 / 012018$

Ocran, T. K., Underwood, E. P. G., \& Arthur, P. A. (2020). Strategies for successful implementation of mobile phone library services. Journal of Academic Librarianship, 46(5), 102174. doi: https://doi.org/10.1016/ j.acalib.2020.102174

Ogunkola, B. J. (2013). Scientific literacy: Conceptual overview, importance and strategies for improvement. Journal of Educationai and Sociai Research, 3(1), 265-274. doi: https://doi.org/10.5901/jesr.2013 .v3 $\mathrm{n} 1 \mathrm{p} 265$

Palmatier, R. W., Houston, M. B., \& Hulland, J. (2018). Review articles: purpose, process, and structure. Journal of the Academy of Marketing Science, 46(1), 1-5. doi: https://doi.org/10.1007/s11747-017-05 63-4

Parmin, P., Sajidan, S., Ashadi, A., \& Sutikno, S. (2015). Skill of prospective teacher in integrating the concept of science with local wisdom model. Jurnal Pendidikan IPA Indonesia, 4(2), 120-126. doi: https://doi.org /10.15294/jpii.v4i2.4179

Purnomo, T. (2020). Plankton diversity in intertidal zone kondang merak beach district of malang, east java. Journal of Physics: Conference Series, 1569(4), 042092. doi: https://doi.org/10.1088/1742-6596/1569/ 4/042092

Rahmaniar, F. S., Suyitno, S., Supana, S., \& Saddhono, K. (2019). Religious value in the local wisdom of Labuhan Kombang Mountain Ngliyep Beach Malang District. 1st Seminar and Workshop on Research Design, for Education, Social Science, Arts, and Humanities. doi: https://doi.org/10.4108/eai.27-4-20 19.2286848

Retno, R. S., \& Yuhanna, W. L. (2016). The learning of science basic concept by using scientifiq inquiry to improve student's thinking, working, and scientific attitude abilities. JPBI (Jurnal Pendidikan Biologi Indonesia), 2(1), 2442-3750. doi: https://doi.org/10.22219/jpbi.v2i1.2703

Rhodes, T. L. (2010). Assesing outcomes and improving achievement: Tips and tools for Using Rubrics. Association of American Colleges and Universities. Retrieved from https://www.aacu.org/sites/default/ files/files/VALUE NALUE_ScientificReasoningRubric.pdf

Riniwati, H., Harahab, N., \& Abidin, Z. (2017). Participation of informal institutions in ecotourism management at Clungup Beach in Southern Malang. International Conference on Electrical Engineering and Informatics (ICELTICS), 488-499. Retrieved from http://www.jurnal.unsyiah.ac.id/AICS-Social/article/ view/10358/8686

Romero-Rodríguez, J. M., Aznar-Díaz, I., Hinojo-Lucena, F. J., \& Cáceres-Reche, M. P. (2020). Models of good teaching practices for mobile learning in higher education. Palgrave Communications, 6(1), 1-7. doi: https://doi.org/10.1057/s41599-020-0468-6

Salter, I. Y., \& Atkins, L. J. (2014). What students say versus what they do regarding scientific inquiry. Science Education, 98(1), 1-35. doi: https://doi.org/10.1002/sce.21084

Sari, H. P. E., Rahayu, S. E., Masjhudi, M., \& Fauziah, F. (2015). Study of butterfly species at Kondang Merak Beach Southern Malang Area. KnE Life Sciences, 2(1), 579. doi: https://doi.org/10.18502/kls.v2i1.220

Semedi, B., Syukron, A. R., \& Lutfi, O. M. (2019). Pemanfaatan data citra satelit Sentinel-2 untuk asesmen habitat dasar perairan pantai selatan Sempu Kabupaten Malang. JFMR-Journal of Fisheries and Marine Research, 3(2), 155-161. doi: https://doi.org/10.21776/ub.jfmr.2019.003.02.19

Sukardia, Mayefis, R., \& Usmeldi. (2020). Development of android based mobile learning media on computer assembly at a vocational high school. International Journal of Innovation, Creativity and Change, 11(4), 347-361. Retrieved from https://www.ijicc.net/images/vol11iss4/11427_Sukardi_2020_E_R.pdf

Sukarno, S., Permanasari, A., \& Hamidah, I. (2013). The profile of science process skill (SPS) student at secondary high school (case study in Jambi). International Journal of Scientific Engineering and Research (IJSER), 1(1), 79-83. Retrieved from https://www.ijser.in/archives/v1i1/MDExMzA5MTg=.pdf

Sung, Y.-T., Chang, K.-E., \& Liu, T.-C. (2016). The effects of integrating mobile devices with teaching and learning on students' learning performance: A meta-analysis and research synthesis. Computers \& Education, 94, 252-275. doi: https://doi.org/10.1016/j.compedu.2015.11.008

Tal, T., \& Tsaushu, M. (2017). Student-centered introductory biology course: evidence for deep learning. Journal of Biological Education, 9266, 1-15. doi: https://doi.org/10.1080/00219266.2017. 1385508 
Teodorescu, A. (2015). Mobile learning and its impact on business english learning. Procedia - Social and Behavioral Sciences, 180, 1535-1540. doi: https://doi.org/10.1016/j.sbspro. 2015.02.303

Vieira, R. D., Melo, V. F. de, Avraamidou, L., \& Lobato, J. A. (2017). Reconceptualizing scientific literacy: The role of students' epistemological profiles. Education Sciences, 7(4), 47. doi: https://doi.org/10.3390/ edu csci7020047

West, D. M. (2015). Connected learning: How mobile technology can imporve education. Center for Technology Innovation at Brookings, December, 1-8. Retrieved from https://www.brookings.edu/wpcontent/uploads/ 2016/07/west_connected-learning_v11.pdf

Yusof, K. M., Hassan, S. A. H. S., Jamaludin, M. Z., \& Harun, N. F. (2012). Cooperative Problem-based Learning (CPBL): Framework for Integrating Cooperative Learning and Problem-based Learning. Procedia - Social and Behavioral Sciences, 56, 223-232. doi: https://doi.org/10.1016/j.sbspro. 2012 .09 .649 